\title{
Effect of Drying Techniques on Functional and Physico-Chemical Properties of Okara
}

\author{
Deepika Ahlawat ${ }^{1}$, Darshna Poonia ${ }^{1}$, Monica Ahlawat ${ }^{2}$ and S.S. Ahlawat ${ }^{1^{*}}$ \\ ${ }^{1}$ Department of Foods and Nutrition, College of Home Science, CCS Haryana Agricultural \\ University, Hisar-125004, Haryana, India \\ ${ }^{2}$ Department of Livestock Products Technology, College of Veterinary Science, LUVAS, \\ Hisar-125004, Haryana, India \\ *Corresponding author
}

\section{A B S T R A C T}

The study was undertaken with an objective to evaluate the effect of drying techniques on functional properties and chemical composition of okara (soybean processing byproduct). The predefined drying techniques like oven, freeze and solar tunnel drying were followed and their effect on the physico-chemical properties of okara were studied. Fresh okara was extracted, processed (dried) and powdered from variety PS-1347. However, fresh okara

\section{Keywords}

Drying technique,

Okara powder,

Physico-chemical properties

Article Info

Accepted:

07 April 2018

Available Online:

10 May 2018 showed higher protein solubility as compared to okara powders irrespective of drying techniques but freeze dried okara had highest protein solubility followed by oven dried and solar tunnel dried okara powders. Water holding capacity was increased due to drying as compared to fresh okara and freeze dried okara powder showed maximum water holding capacity. Drying also decreased significantly the bulk density with minimum values in freeze dried okara powder. However, drying significantly increased the phytic acid contents, total phenolic contents, protein digestibility and antioxidant activities as compared to fresh okara, but freeze drying technique showed lowest value for phytic acid and highest values for total phenolic contents, protein digestibility and antioxidant activities among all the drying methods. However, moisture, protein and ash content in all the three types of dried okara powders were statistically similar, but fat content was higher in oven dried and minimum in freeze dried okara powder. Freeze dried okara powder had maximum content of crude, total dietary fibre, soluble and insoluble dietary fibre, whereas oven dried okara powder had minimum content of total dietary, soluble and insoluble dietary fibre. Total calcium, phosphorus, potassium and iron content and available calcium and iron contents were found abundantly in freeze dried okara powder. It is concluded that freeze drying is better technique with improved physico-chemical properties of okara powder as compared to oven and solar tunnel drying.

\section{Introduction}

Okara, a Japanese word meaning "honorable hull" represents soy pulp, is a by-product of soy milk processing having low commercial value and potentially nutritious product with high in fiber, protein, carbohydrates, vitamins, minerals and fat having excellent functional properties (Li et al., 2012; Pinto; Castro, 2008). Its massive generation and perishability 
due to high moisture content attracts considerable attention towards drying of okara (Cuadros et al., 2011). However, it must be dried quickly to avoid spoilage and to prolong its shelf life, but drying method have a significant effect on the functional and nutritional properties of okara. During drying one of the most important aspects to be considered is the preservation of the protein quality, which can be affected by the drying conditions (Redondo-Cuenca et al., 2008). The high quality protein fraction is responsible for water holding, fat binding and emulsifying capacity including foaming properties and anti-hypertension effects influence the production and quality of a determined food product (Silva et al., 2006; Aplevicz et al., 2000).

It is also of important concern that intense heat treatment denatured the proteins and fibres present in okara which reduced the protein solubility and water holding capacity (Aguado, 2010). Reports are there that vaccum-tray drying is more effective to produce good quality okara in respect of its functional, nutritional and shelf life characteristics than microwave drying, but it is costly (Sengupta et al., 2012). Hence, keeping these factors in view, this study was conducted to evaluate the effect of different drying techniques on physico-chemical properties of okra.

\section{Materials and Methods}

Soybean variety, PS-1347 was procured in a single lot from the Department of Genetics and Plant Breeding, College of Agriculture, CCS Haryana Agricultural University, Hisar. The seeds were cleaned and made free of dust, dirt and foreign materials prior to processing. For the extraction of okara, soybean seeds were washed and soaked overnight in water. Fresh okara was extracted using hot disintegration method (Bourne, 1976) with the help of SOYCOW machine, Department of Processing and Food Engineering, College of Agriculture Engineering and Technology, CCS Haryana Agriculture University, Hisar.

The fresh extracted okara was dried by applying three different drying techniques i.e. hot air oven drying $\left(55^{\circ} \mathrm{C}\right.$ for $\left.12 \mathrm{~h}\right)$, freeze drying $\left(-50{ }^{0} \mathrm{c}\right.$ for $\left.24 \mathrm{~h}\right)$ in Bench Top Freeze Dryer (Model no FD-1A-50) and solar tunnel dryer. Dried okara was ground to fine powder and kept in air tight containers till further analysis.

Proximate composition and crude fibre (using automatic Fibra- Plus apparatus) was estimated by following the standard methods of analysis (AOAC, 2000). Protein solubility (Morr et al., 1985) was evaluated by dissolving $500 \mathrm{mg}$ sample in $25 \mathrm{ml}$ saline solution $(0.1 \mathrm{M} \mathrm{NaCl})$ in a conical flask, followed by centrifugation at $3000 \mathrm{rpm}$ for 10 minutes. The supernatant was collected and estimated for soluble protein contents by the Micro Kjeldahl method (AOAC, 2005).

Soluble and insoluble dietary fibre was determined by enzymatic method (Furda, 1981) and the sum of insoluble and soluble fibre contents represented the total dietary fibre.

Water holding capacity (g water/g protein) was determined by dissolving $100 \mathrm{mg}$ sample in $3.5 \mathrm{ml}$ distilled water in a transparent $50 \mathrm{ml}$ centrifuge tube. The mixture was vortexed for $2 \mathrm{~min}$, left to rest for $30 \mathrm{~min}$ and then centrifuged $\left(20^{\circ} \mathrm{C}, 18,000 \times \mathrm{g}\right)$ for $10 \mathrm{~min}$. Supernatant was removed and the centrifuged tubes were turned upside down for $30 \mathrm{~min}$ and weighed (hydrated sample + tube weight) for calculation of water holding capacity as per the method prescribed by Quinn and Paton (1979). The bulk density $\left(\mathrm{g} / \mathrm{cm}^{3}\right)$ of sample was analyzed by using the method of Wang and Kinsella (1976). 
Iron, calcium and potassium in acid digested samples were determined by Atomic Absorption Spectrophotometer (Lindsey and Norwell, 1969). Available calcium (Kim and Zemel, 1986) and ionizable iron (Rao and Prabhavati, 1978) were also extracted.

In vitro protein digestibility was determined by following the modified method of Mertz et al., (1983). Phytic acid (Davies and Reid, 1979), total phenolic contents (Singleton and Rossi, 1965) and free radical scavenging activity (DPPH RSA) in the sample was evaluated by using the DPPH method of Hatano et al., (1988).

\section{Results and Discussion}

\section{Functional properties}

A decrease in protein solubility due to all the three drying technique in dried products was observed as compared to fresh okara (Table 1). Carmen et al., (2012) also reported higher values for protein solubility of fresh okara as compared to okara powder. Among three types of drying, protein solubility was maximum in freeze dried okara followed by oven dried and solar tunnel dried okara powder. These observed values for protein solubility of dried okara powder in present study are in close agreement to the values reported by Grizotto and Aguirre (2009). Wagnor and Anon (1990) and Ma et al., (1997) also explained that protein solubility increases with the retention of good quality protein in hypocotyls which do not get denatured while drying treatments.

The water holding capacity in fresh okara was significantly lower than the dried products. It might be due to retention of high protein and fibre content in dried okra. Okara dried by freeze drying method showed highest water holding capacity and lowest was observed in solar tunnel dried okara powder. These findings are in accordance with the results of Grizotto and Aguirre (2011).

Fresh okara had $0.99 \mathrm{~g} / \mathrm{cm}^{3}$ bulk density while in dried okara it decreased in the range from 0.26 to $0.30 \mathrm{~g} / \mathrm{cm}^{3}$. These results are in agreement with the findings of Ndife et al., (2014) for bulk density in composite flour containing okara.

Phytic acid content of all the three types of dried okara was increased as compared to control $(602.79 \mathrm{mg} / 100 \mathrm{~g})$ and ranged from 786.50 to $801.79 \mathrm{mg} / 100 \mathrm{~g}$, being highest in oven dried okara powder followed by solar tunnel and freeze dried okara powder (798.02 and 786.50, respectively). These values were within the range of Van der Reit (1989) reports $(500-1200 \mathrm{mg} / 100 \mathrm{~g})$ but higher than the values $(611.80 \mathrm{mg} / 100 \mathrm{~g})$ reported by Vineeta and Greawal (2001) in oven dried okara powder. O' Toole (1999) explained that phytic acid content depends on the cultivar of soybean and the production method.

Similar to pytic acid contents, the total phenolic content of dried okara powder was also increased as compared to control (63.65 $\mathrm{mg}$ gallic acid/100g) in present investigation and ranged from 74.28 to $83.75 \mathrm{mg} / 100 \mathrm{~g}$, being highest in freeze dried and lowest in oven dried okara powder. Almost similar values were reported by Tabart et al., (2007), while Singh et al., (2012) reported higher values $(116 \mathrm{mg} / 100 \mathrm{~g})$ for total phenolic content in okara powder. By increasing the temperature and solvent fraction, total polyphenolic content decreased significantly, this is due to the degradation of polyphenols and decrease in the polarity of solvent at higher temperature (Tsubaki et al., 2009). Phenolics are secondary metabolites, and in part, are produced as a result of the plant's interaction with the environment and variation in total phenolic content reported by earlier workers underlines the variation in the process 
or in the raw material (Snyder and Nicholson, 1990).

Though freeze dried okara powder had highest protein digestibility (89.58 per cent) followed by solar tunnel, oven dried and fresh okara (88.49, 87.35 and 64.10 per cent, respectively).

The intensive heat may denature the protein and reduce the in vitro digestibility in solar tunnel and oven dried okra powders (Aguado, 2010). Further phenolic compounds or their oxidized product forms complexes with essential amino acids, enzymes and proteins, thus lowering their protein (Shahidi and Naczk, 1992). Improvement in protein digestibility of freeze dried okara powder is possibly due to reduction in levels of antinutritional factors like phytic acid after soaking and heat treatments (Mateos- Aparicio et al., 2010)

In vitro experiments have also indicated that okara powder is more potential source of antioxidant components (Amin and Mukhrizah, 2007) as compared to fresh okra. Freeze dried okara powder contained maximum amount of antioxidant activity, while oven and solar tunnel dried okara powder showed almost similar antioxidant activity. The similar findings were also reported by various workers (Singh et al., 2011).

\section{Chemical composition}

Moisture content of fresh okara (Table 2) was in close agreement to the range mentioned by Li et al., (2008).

Table.1 Effect of drying techniques on functional properties of okara $(n=6)$

\begin{tabular}{|c|c|c|c|c|}
\hline \multirow{2}{*}{ Parameters } & \multicolumn{4}{|c|}{ Treatments } \\
\hline & Control & $\begin{array}{l}\text { Oven dried } \\
\text { okara }\end{array}$ & $\begin{array}{c}\text { Freeze dried } \\
\text { okara }\end{array}$ & $\begin{array}{l}\text { Solar tunnel } \\
\text { dried okara }\end{array}$ \\
\hline $\begin{array}{l}\text { Protein } \\
\text { solubility } \\
\text { (g soluble } \\
\text { protein/100 g) }\end{array}$ & $24.40^{\mathrm{c}} \pm 0.01$ & $20.60^{\mathrm{a}} \pm 0.01$ & $23.10^{\mathrm{b}} \pm 0.01$ & $20.10^{\mathrm{a}} \pm 0.02$ \\
\hline $\begin{array}{l}\text { Water holding } \\
\text { capacity (g } \\
\text { water/g protein) }\end{array}$ & $07.47^{\mathrm{a}} \pm 0.02$ & $17.83^{b} \pm 0.82$ & $22.96^{c} \pm 0.35$ & $17.04^{\mathrm{b}} \pm 0.01$ \\
\hline $\begin{array}{l}\text { Bulk density } \\
\left(\mathrm{g} / \mathrm{cm}^{3}\right)\end{array}$ & $0.99^{c} \pm 0.01$ & $0.28^{\mathrm{ab}} \pm 0.01$ & $0.26^{\mathrm{a}} \pm 0.02$ & $0.30^{\mathrm{b}} \pm 0.01$ \\
\hline $\begin{array}{l}\text { Phytic acid } \\
\text { (mg/100g) }\end{array}$ & $602.79^{a} \pm 12.42$ & $801.79^{c} \pm 12.54$ & $786.50^{b} \pm 9.39$ & $798.02^{c} \pm 11.42^{b}$ \\
\hline $\begin{array}{l}\text { Total phenolic } \\
\text { content (mg } \\
\text { gallic acid/100g) }\end{array}$ & $63.65^{\mathrm{a}} \pm 0.59$ & $74.28^{b} \pm 0.03$ & $83.75^{\mathrm{d}} \pm 0.05$ & $79.62^{c} \pm 0.04$ \\
\hline $\begin{array}{l}\text { In vitro protein } \\
\text { digestibility }(\%)\end{array}$ & $64.10^{\mathrm{a}} \pm 0.67$ & $87.35^{\mathrm{b}} \pm 0.52$ & $89.58^{\mathrm{d}} \pm 0.83$ & $88.49^{c} \pm 0.49$ \\
\hline $\begin{array}{l}\text { Antioxidant } \\
\text { activity }(\%)\end{array}$ & $26.68^{\mathrm{a}} \pm 1.42$ & $36.52^{b} \pm 1.05$ & $43.56^{c} \pm 2.16$ & $36.59^{b} \pm 0.86$ \\
\hline
\end{tabular}

Mean \pm SE with different superscripts in rows differ significantly $(\mathrm{P} \leq 0.05)$ 
Table.2 Effect of drying techniques on chemical composition of okara (dry weight basis)

\begin{tabular}{|c|c|c|c|c|}
\hline \multirow[b]{2}{*}{ Parameter } & \multicolumn{4}{|c|}{ Types of drying } \\
\hline & Control & Oven drying & Freeze drying & Solar tunnel drying \\
\hline \multicolumn{5}{|c|}{ Proximate composition (\%) } \\
\hline Moisture & $80.08 \pm 0.03$ & $6.51 \pm 0.01^{\mathrm{a}}$ & $6.44 \pm 0.04^{\mathrm{a}}$ & $6.48 \pm 0.05^{\mathrm{a}}$ \\
\hline Protein & $4.61 \pm 0.09$ & $23.14 \pm 0.98^{\mathrm{a}}$ & $24.98 \pm 0.62^{\mathrm{a}}$ & $24.04 \pm 0.85^{\mathrm{a}}$ \\
\hline Fat & $3.27 \pm 0.34$ & $7.81 \pm 0.33^{\mathrm{a}}$ & $5.83 \pm 0.60^{\mathrm{b}}$ & $6.85 \pm 0.68^{\mathrm{ab}}$ \\
\hline Ash & $0.65 \pm 0.82$ & $3.80 \pm 0.42^{\mathrm{a}}$ & $3.92 \pm 0.38^{\mathrm{a}}$ & $3.67 \pm 0.14^{\mathrm{a}}$ \\
\hline Crude fibre & $2.26 \pm 0.19$ & $27.54 \pm 0.28^{\mathrm{ab}}$ & $28.58 \pm 0.32^{\mathrm{a}}$ & $27.08 \pm 0.34^{\mathrm{b}}$ \\
\hline \multicolumn{5}{|c|}{ Dietary fibre (\%) } \\
\hline Total dietary fibre & $11.59 \pm 0.03$ & $49.27 \pm 0.25^{\mathrm{c}}$ & $52.83 \pm 0.15^{\mathrm{a}}$ & $50.80 \pm 0.11^{\mathrm{b}}$ \\
\hline Soluble dietary fibre & $1.33 \pm 0.18$ & $4.06 \pm 0.01^{c}$ & $4.71 \pm 0.17^{\mathrm{a}}$ & $4.31 \pm 0.13^{\mathrm{b}}$ \\
\hline Insoluble dietary fibre & $10.25 \pm 0.21$ & $45.21 \pm 0.06^{\mathrm{c}}$ & $48.12 \pm 0.01^{\mathrm{a}}$ & $46.49 \pm 0.18^{b}$ \\
\hline \multicolumn{5}{|c|}{ Total minerals $(\mathrm{mg} / 100 \mathrm{~g})$} \\
\hline Calcium & $72.43 \pm 0.03$ & $303.79 \pm 2.34^{\mathrm{c}}$ & $372.40 \pm 1.49^{\mathrm{a}}$ & $324.43 \pm 0.76^{\mathrm{b}}$ \\
\hline Phosphorus & $89.28 \pm 0.86$ & $383.29 \pm 0.96^{\mathrm{ab}}$ & $401.53 \pm 0.79^{\mathrm{a}}$ & $379.66 \pm 3.59^{b}$ \\
\hline Iron & $1.43 \pm 0.82$ & $7.01 \pm 0.01^{\mathrm{c}}$ & $8.48 \pm 0.23^{\mathrm{a}}$ & $7.65 \pm 0.01^{\mathrm{b}}$ \\
\hline Potassium & $327.51 \pm 1.21$ & $1291.51 \pm 0.69^{b}$ & $1361.94 \pm 0.58^{\mathrm{a}}$ & $1275.59 \pm 3.05^{\mathrm{c}}$ \\
\hline \multicolumn{5}{|c|}{ A vailable minerals $(\mathrm{mg} / 100 \mathrm{~g})$} \\
\hline Calcium & $23.61 \pm 2.34$ & $42.96 \pm 0.02^{c}$ & $43.56 \pm 0.11^{\mathrm{a}}$ & $43.45 \pm 0.02^{b}$ \\
\hline Iron & $0.69 \pm 0.07$ & $23.15 \pm 0.07^{\mathrm{c}}$ & $24.02 \pm 0.13^{\mathrm{a}}$ & $23.57 \pm 0.00^{\mathrm{b}}$ \\
\hline
\end{tabular}

Mean \pm SE with different superscripts in rows differ significantly $(\mathrm{P} \leq 0.05)$

The values observed in present study for crude protein, fat, ash and crude fibre in fresh okara were well within the range reported by Fafaungwithayakul et al., (2011) and Sengupta et al., (2012).

In present study, fat content was lowest in freeze dried okara powder as compared to oven and solar tunnel dried okara powder.

These values are somewhat lower than the values observed by earlier workers (Lie et al., 2008; Lescano et al., 2005).

Ash content of oven, freeze and solar tunnel dried okara powder differed non-significantly from each other. Almost similar values for ash content were reported by Mateos-Aparicio et al., (2010) and Lu et al., (2013) in tray dried and freeze dried okara powder, respectively.
It was noticed that freeze dried okara contained maximum amount of crude fibre followed by oven and solar tunnel dried okara powder. Grizotto et al., (2012) stated that intensive heat treatment ruptures the microstructure of fibres, while Wang et al., (2010) observed the significant influence of cultivar and cropping year on the crude fibre contents. Li et al., (2012) reported that okara can partially replace wheat flour, soy flour and other ingredients for food production to increase the contents of fibre and protein.

In present study freeze dried okara powder had highest amount of total, soluble and insoluble dietary fibre and lowest amount was found in oven dried okara powder. Renaldi and Bennink (2000) observed that oven drying ruptures the fibre structure of okara. Almost similar values for total, soluble and insoluble dietary are reported by Mateos- 
Aparicio (2010). Okara may be considered as a good source of dietary fibre because it is the major constituent, which is very rich in insoluble dietary fibre (Li et al., 2008).

Freeze dried okara contained significantly higher amounts of minerals i.e. calcium, phosphorus, iron and potassium as compared to oven dried and solar tunnel dried okara powder. In present study, it was noticed that potassium was the most abundant mineral element in fresh okara followed by phosphorus, calcium, iron. Vineeta and Grewal (2001) also reported almost similar values for iron, whereas, Stanojevic et al., (2014) reported higher values for minerals (calcium, phosphorus, iron and potassium in fresh okara). Alpaslan (2002) stated that either soymilk preparation process (from soaking to grinding) or the quality of raw material (seed variety, quality and cultivation) effects the mineral composition in okara. The values of calcium, phosphorus, iron and potassium observed in present investigation fall between the values mentioned by MateosAparicio et al., (2010) and Wang et al., (2010) but Lu et al., (2013) reported higher values for calcium and iron and lower values for potassium. Such variations in mineral content might be due to the differences in their genetic origin, location, soil moisture content, minerals nutrient availabilities and organic matter content (Wang and Daun, 2004).

The available calcium and iron content of fresh okara was 23.61 and $0.69 \mathrm{mg} / 100 \mathrm{~g}$, respectively. However, Vineeta and Grewal (2001) reported higher values for available calcium and iron but Hurell et al., (2003) explained that when foods are reconstituted with water, dephytinization increases iron absorption and O'Toole (1999) reported that the chemical composition of okara will depend on the amount of water phase extracted from the ground soybean and whether further water was added to extract residual extractable compounds and it also depends on the cultivar of soybean and the production method. Freeze dried okara powder contained significantly higher amount of available calcium and iron followed by solar tunnel and oven dried okara powder.

Freeze dried okara powder had higher protein solubility, water holding capacity total phenolic contents, total dietary fibre, soluble and insoluble dietary fibre, protein digestibility and antioxidant activities with lower bulk density and, phytic acid and fat contents among all the drying methods. Total calcium, phosphorus, potassium and iron content and available calcium and iron contents were found abundantly in freeze dried okara powder. It is concluded that freeze drying is better technique with improved phyco-chemical properties of okara powder as compared to oven and solar tunnel drying.

\section{References}

Aguado. A. (2010). Development of okara powder as a Gluten free alternative to all purpose flour for value added use in baked Goods. M.Sc. Thesis, University of Maryland.

Alpaslan. M. and Hayta. M. (2002). Hydration properties, soymilk and okara yield of soybean affected by agronomic factors. Nahrung-Food 46:141-143.

Amin, I, Mukhrizah, O. (2006). Antioxidant capacity of methanolic and water extracts prepared from food processing by-products. J Sci Food Agric.71:720727.

AOAC, 2000. Official methods of analysis of association of official analytical chemist. Washington D.C.

AOAC. 2005. Official Methods of Analysis of AOAC International. 18th ed. Maryland 
Aplevicz, K.S, Demiate, I.M. (2000). Analysis of physicochemical properties of okara. Cienc.Agrotech. 31:14161422 .

Carmen C.M., A. Martín-Cabrejas, Y Aguilera, Mercedes M. Pedrosa, Teresa Hernández, Soledad Díaz, Rosa M. Esteban. (2012). The impact of dehydration process on antinutrients and protein digestibility of some legume flours. J. Food Process Technol. 114: 1063-1068.

Cuadros, F., F. L' opez-Rodr'1guez, A. RuizCelma, F. Rubiales, and A. Gonz'alezGonz'alez. (2011). "Recycling, reuse and energetic valuation of meat industry wastes in extremadura (Spain)," Resources, Conservation and Recycling, vol. 55, no. 4, pp. 393- 399.

Davies, N.T and Reid, H. (1979). An evaluation of phytates, zinc, copper, iron and magnesium content and availability of soya based textured vegetable, protein meat substitute or meat extruders. Brit. J. Nutr. 41:579589.

Fafaungwithyakul. N., Hongsprabhas. P., and Hongsprabhas. P. (2011). "Effect of soy soluble polysaccharide on the stability of soystabilised emulsion during in vitro protein digestion," Food Biophysics, 6: $407-415$.

Furda, I. (1981). Simultaneous analysis of soluble dietary fibre. The analysis of dietary fibre in Food. W.P.T. James and O. Theander (Eds.) Marcel Dekkar, New York: 163-172.

Grizotto, R. K. and Aguirre J.M. (2009). The study the drying of the soymilk residue in a pneumatic flash dryer Simpósio Latino Americano De Ciência E Tecnologia De Alimentos, Campinas: SBCTA,

Grizotto. R.F, Andrade. J., Miyagusku. L., and Yamada. E.A. (2012). Physical, chemical, technological and sensory characteristics of Frankfurt type sausage containing okara flour. Cienc Tecnol. Aliment, Campinas. 32: 538-546.

Grizotto. R.K. and Aguirre J.M. (2011). Study of the flash drying of the residue from soymilk processing-okara. Technol Aliment Campinas. 31:645-653.

Hatano, T., Kagawa, H., Yasuhara, T. and Okuda, T. (1988). Two new flavonoids and other constitutes in licorice root; their relative astringency and radical scavenging effects. Chem. Pharma, Bull. 36: 2090-2097.

Hurrell. R.F., Reddy. M.B, Marcel-A J and Jamnes. D.C. (2003). Degradation of phytic acid in cereal porriadges improves iron absorption by human subjects. Am J Clin Nutr. 77:1213-1219.

Kim, H. and Zemel, M.B. 1986. In vitro estimation of potential bioavailability of calcium for sea mustard milk and spinach under stimulate normal and reduce gastric condition. J. Food Sci. 51: 957-963.

Li, B., Qiao, M, Lu, F. (2012). Composition, nutrition and utilization of okara (soybean residue). Food Reviews Int. 28: 231-252.

Lie, C.H, Wei, Y.T., Chou, C.C. (2008). Enhanced antioxidant activity of soybean koiji prepared with various filamentous fungi. Food Microbial. 23: 628-633.

Lindsey, W.A. and Norwell, M.A. (1969). A new DPTA-TEA soil test for zinc and iron. Agron. Abst. 61:84-89.

Lu, F., Cui, Z., Liu, Y. and Li, B. (2013). The Effect of Okara on the Qualities of Noodle and Steamed Bread. Adv J. Food Sci Technol. 5 (7): 960-968

Ma, C. Y. Liu WS, Kwok. K.C. and Kwok F. (1997). Isolation and characterization of proteins from soymilk residue (okara). Food Research Inter. 29:799-805.

Mateos-Aparicio I, Mateos-Peinado C, Jiménez-Escrig $\mathrm{A}$ and Rupérez $\mathrm{P}$. 
(2010). Multifunctional antioxidant activity of polysaccharide fractions from the soybean byproduct okara. Carbohydrate Polymers, 82: 245-250.

Mateos-Aparicio I, Mateos-Peinado C, Rupérez P. (2010). High hydrostatic pressure improves the functionality of dietary fiber in okara by-product from soybean. Innovatv Food Sci Emerg Tech, 11: 445-450.

Mertz, E.T., Kitlers, A.W. and Aretell. J.D. (1983). In vitro digestibility of protein in major food cereals. Fed. Proc., 42(5):6026-6028.

Morr, C.V. German, B., Kinsella, J. E., Regenstein, J. M., Van Buren, J. P., Kilara, A., Lewis, B. A., Mangino, M. E. et al., (1985). Collaborative study to develop a standardized food protein solubility procedure. J.Food.Sci., 50:1715-1718.

Ndife, Joel, Fatima, Kida and Stephen, Fagbemi. (2014). Production and quality assessment of enriched cookies from whole wheat and full fat soya. European.J. Food Sci. Technol. 2: 19 28.

O'Toole, D.K. (1999). Characteristics and use of okara, the soybean residue from soy milk production A review. J. Agric. Food Chem., 47: 363-371.

Pinto, D.D.J., Castro, P.S., (2008). Estudo preliminary de secagem do okara pere inativacao dos factores antinutricionais e conservacao. Brazilian J Food Tech. 18: 125-131.

Quinn, J.R. and Paton, D. (1979). A practical measurement of water hydration capacity of protein materials. Cereal Chem. 56: 38-40.

Rao, B.S.N and Prabhavathi, T. (1978). An in vitro method of predicting the bioavailability of iron from Food. Am. J. Clin. Nutri. 31:169.

Recundo-Cuenca A, Villaneuva-Suárez MJ and Mateos-Aparicio I. (2008). Soybean seeds and its by-product okara as sources of dietary fibre. Measurement by AOAC and Englyst methods. Food Chem., 108:1099-1105.

Renaldi Vea, Ngpkw and Bennink. (2000). Effects of extrusion on dietary fiber and isoflavone contents of wheat extrudates enriched with wet okara. Cereal Chem. 77: 237-240.

Satanjoevic S., Miroljub. B.B., Pesic M., Sladana Z., Kresovic M irjana, Biljana. (2014). Mineral Elements, Lipoxygenase Activity Capacity of okara as a byproduct in Hydrothermal Processing of Soy milk. J Agri. Food Chem., 62: 9017-9023.

Sengupta. S., Chakraborty. M., Bhowal. J. And Bhattacharya. D. K. (2012). Study on the effects of drying process on the composition and quality of wet okara. Int J. Sci. Environ Technol., 1: 319-330.

Shahidi. F. And Naczk. (1992). Phenolic antioxidant. Reviews: Review: Food Sci. Nutri., 32: 67-103.

Silva, L.G., Silva; J.B., Costa, V.S. nad Neto, F.D.G. (2006). 'Utilization of okara, an agroindustrial residue of soy, in the manufacturing process of sandwhich loaf". J Food Sci., 23: 193-199.

Singh. V., Vishwanthan. K.H. and Subramanian.R. (2011). "Influence of particle size on protein extractability from soybean and okara." $J$ Food Engg., 102: 240-246.

Singh. V.K., Kulia. A, Yadav. G and Baneerje. B. (2012). Phenolic content in okara. Food Technol. Biotechnol. 9: 3238.

Singleton, V.L. and Rossi, J.A. (1965). Calorimetry of total phenols with phosphomolybdic phosphotungstic acid reagents. Am. J. Ecology Viticulture 16: 144-158.

Synder B.A., Nicholson R.J. (1990). Synthesis of phytoalexins in sorghum as 
a site- specific response to fungal ingress. J. Food Sci. 248: 1637-1639.

Tabard, J; Kevers, C., Spiel, A., Pincemail, J., Dommes. (2007). Optimization of extraction of phenolics and antioxidants from black currant leaves and buds and of stability during storage. Food Chem. 105: 1268-1275.

Tsubaki, S., Michiyo Nakauchi, Yoshihiko Ozaki and Jun-ichi azuma. (2009). Microwave Heating for Solubilization of Polysaccharide and Polyphenol from Soybean Residue (Okara). Food Sci. Technol. Res., 15 (3): 307 - 314.

Vander Reit W.B., Wight. A., Cillers. J.L. and Datel J.M. (1989). Food chemical investigation of tofu and byproducts okara. Food Chem. 34: 193-202.

Vineeta and Grewal, R. (2001). Drying kinetics and quality of soy residue (okara) dried in a jet spouted-bed dryer. Drying Technol. 23 (6):1229-1242. Absorbing capacity of soyprotein isolates. J. Food Sci. 55:765-770.

Wagnre, J.R, Anon, M.C. (1990). Influence of denaturation, hydrophobicity and sulfhydryl content on solubility and water

Waliszewski KN, Pardio V and Carreon E. (2002). Physicochemical and sensory properties of corn tortillas made from nixtamalized corn flour fortified with spent soymilk residue (okara). J. Food. Sci, 67: 3194-3197.

Wang N, Daun J.K. (2004). Effect of variety and crude protein content on nutrient and certain antinutrient field peas (Pisum sativum). J. Sci Food Agri.84:1021-1029.

Wang, J.C. and Kinsella, J.E. (1976). Functional properties of novel proteins. Alfafa leaf protein. J. Food Sci. 41: 286-292.

Wang, N., Hatcher, W.D., Warkentin, T.D., Tooews, R. (2010). Effect of cultivar and environment on physicochemical and cooking characteristics of field pea. Food Chem., 118:109-115.

Xie, M., Hugg, H., Hsieh, F. and Mustapha, A. (2008). Puffing of okara/rice blends using a rice cake machine. J. Food. Sci., 73: E341-E348.

\section{How to cite this article:}

Deepika Ahlawat, Darshna Poonia, Monica Ahlawat and Ahlawat, S.S. 2018. Effect of Drying Techniques on Functional and Physico-Chemical Properties of Okara. Int.J.Curr.Microbiol.App.Sci. 7(05): 582-590. doi: https://doi.org/10.20546/ijcmas.2018.705.072 